\title{
Type D personality and predictive factors of body mass index in bariatric surgery candi- dates
}

\author{
Bariatrik cerrahi adaylarında D Tipi kişilik ve vücut kitle indeksinin \\ yordayıcı faktörleri
}

\author{
İbrahim Yağcı¹, Yasin Taşdelen², Okay Koç³, Yüksel Kıvrak ${ }^{4}$ \\ ${ }^{1}$ M.D., Kars Harakani State Hospital,department of Psychiatry, Kars, Turkey https://orcid.org/0000-0003-0755-2695 \\ 2M.D., Firat University, Aydın State Hospital, Department of Psychiatry, Aydın, Turkey https://orcid.org/0000-0003-4985-0690 \\ 3 M.D., Department of Gastroenterology Surgery, Aydın, Turkey https://orcid.org/0000-0002-9587-4493 \\ ${ }^{4}$ Assis. Prof., Department of Psychiatry, Afyonkarahisar Health Sciences University Faculty of Medicine, Afyon, Turkey \\ https://orcid.org/0000-0002-6568-2853
}

\begin{abstract}
SUMMARY
Objective: This study aimed to investigate depressionanxiety levels, sexual lives, childhood traumatic experiences, self-esteem, eating attitudes, and Type D personality traits in bariatric surgery candidates. Method: Our study was conducted between June 2019 and December 2019 and included a total of 100 individuals, 50 bariatric surgery candidates and 50 healthy people. A sociodemographic data form, the Beck Depression Inventory, the Beck Anxiety Inventory, the Childhood Trauma Questionnaire, the Type D Personality Scale, the Arizona Sexual Experiences Scale, the Rosenberg Self-Esteem Scale, and the Eating Attitudes Test were used in our study. Results: The scores of Type D Personality, Arizona sexual experiences, childhood trauma, eating attitude, and self-esteem scales were significantly higher in the patient group than in the control group. There was no statistically significant difference between the anxiety and depression scores of both groups. In addition, it was found that the predictive factors of the Body Mass Index were education, self-esteem, eating attitude, and childhood traumas, explaining $63.5 \%$ of the variance. Type $D$ personality, on the other hand, was not found to be one of the predictive factors. Discussion: Bariatric surgery candidates undergoe routine psychiatric examinations prior to their operations, and preoperative follow-up interviews with a psychiatrist is believed to be important for these individuals.
\end{abstract}

Key Words: Bariatric surgery, D Type personality, obesity, body mass index, childhood trauma

\section{ÖZET}

Amaç: Çalışmamızın amacı bariatrik cerrahi adaylarında depresyon-anksiyete düzeylerinin, cinsel yaşantılarının, çocukluk çağı travmatik yaşantılarının, benlik saygıları, yeme tutumları ile D Tipi kişilik özelliklerinin araştırılmasıdır. Yöntem: Çalışmamız Haziran 2019Aralık 2019 tarihleri arasında yapılmış olup 50 bariatrik cerrahi adayı ile 50 sağlıklı kişi olmak üzere toplam 100 kişi alınmıştır. Çalışmamızda sosyodemografik veri formu, Beck Depresyon Ölçeği, Beck Anksiyete Ölçeği, Çocukluk Çağı Travmaları Ölçeği, D Tipi Kişilik Ölçeği, Arizona Cinsel Yaşantılar Ölçeği, Rosenberg Benlik Saygısı Ölçeği, Yeme Tutum Testi kullanılmıştır. Bulgular: Obezite grubunda kontrol grubuna göre daha sık D tipi kişilik örüntüsü, cinsel yaşantılarda ve benlik saygısında bozukluk, yaşam kalitesinde bozulma ve daha sık çocukluk çağı travmaları görülmüş olup anksiyete ve depresyon skorları arasında istatistiksel olarak anlamlı olarak farklılık tespit edilmemiştir. Ayrıca Vücut Kitle İndeksi'nin yordayıcı faktörlerinin eğitim, benlik saygısı, yeme tutumu, çocukluk çağı travmaları olduğu, varyansın \%63.5'ini açıkladığı tespit edilmiştir. D tipi kişiliğin ise yordayıcı faktörlerden olmadığı tespit edilmiştir. Sonuç: Bariatrik cerrahi adayları rutin olarak operasyonları öncesinde psikiyatrik muayeneleri yapılmakta olup ameliyat sonrası dönemde de bu kişilerin psikiyatrist ile kontrol görüşmelerinin yapılmasının önemli olduğu düşünmekteyiz.

Anahtar Sözcükler: Bariatrik cerrahi, D Tipi Kişilik, obezite, Vücut kitle indeksi, çocukluk çağı travmaları 


\section{INTRODUCTION}

Obesity is one of the major public health problems throughout the world. Psychiatric disorders such as depression and anxiety are more common in individuals with obesity $(1,2)$. Furthermore, the quality of life decreases in these individuals (3). Body Mass Index (BMI) has been reported to be associated with physical limitation and fatigue (4). The prevalence of psychosocial problems such as sexual dysfunction, unhappy marriage, and dissatisfaction with appearance is also higher $(5,6)$. In the United States, $33.2 \%$ of women and $27.6 \%$ of men have a BMI of $30 \mathrm{~kg} / \mathrm{m} 2$ and above (7). The incidence of obesity is gradually increasing, not only in the United States of America but also in Turkey and other countries. In Turkey, $41.5 \%$ of women and $21.2 \%$ of men are obese (8).

The increase in BMI value increases both general medical and psychiatric morbidity and mortality rates. The BMI value of $30-35 \mathrm{~kg} / \mathrm{m} 2,35-40 \mathrm{~kg} / \mathrm{m} 2$, and $40 \mathrm{~kg} / \mathrm{m} 2$ and above is defined as Grade 1, Grade 2, and Grade 3 obesity, respectively (9). Mortality is two times higher in individuals with Grade 2 and Grade 3 obesity compared to those with normal weight. Particularly in young individuals with obesity, decreased life expectancy is increased. This decrease in life expectancy increases up to twenty years in Grade 3 obesity (10). Medical comorbidities such as hypertension, hyperlipidemia, diabetes, obstructive sleep apnea, and hypertension decrease with the decrease in weight (1). The decrease in BMI provides an improvement in the quality of life of individuals and a decrease in mortality in the long term.

The search for the treatment for obesity has been ongoing for many years. Although individuals can lose weight with non-surgical methods, $66 \%$ of patients regain the weight they lose within 24 months. The compliance of individuals to the diet program during the medical treatment can create an idea regarding the compliance of the patients to the treatment after surgical intervention. Surgical intervention has come to the fore in the treatment of morbid obesity since it causes early deaths due to comorbid diseases and becomes epidemic $(11,12)$. There are many opinions regarding the weight gain in the postoperative period. Psychological factors have been reported to have an important role. The incidence of psychiatric disorders is high in individuals who will undergo bariatric surgery. About $66 \%$ of these patients have at least one psychiatric disorder in their history. The rate of Axis-I and Axis-II diagnosis in individuals hospitalized for surgery is $38 \%$ and $29 \%$, respectively (13).

The levels of negative affectivity (NA) and social inhibition (SI) are high in type D personality, also called distressed personality (14). There are studies showing that type $\mathrm{D}$ personality is associated with an unhealthy lifestyle. In a recent study, Type D personality has been shown to be much more common in men with a sedentary lifestyle (45\%) compared to those who do exercise regularly (14\%) (15). Furthermore, individuals with type D personality have been found to have irregular eating habits and to take care of their health less (15).

Individuals with obesity, who underwent surgical intervention, should make changes in their eating habits and lifestyle in the postoperative period. Since these changes are effective in postoperative success, it is important to identify the psychiatric and psychosocial characteristics and personality patterns of candidates for bariatric surgery. For this reason, numerous researches have been and are being conducted on these issues. Although there are many studies in the literature evaluating depression-anxiety levels, quality of life, sexual life, childhood traumas, and self-esteem of patients applying for bariatric surgery, there is no study evaluating type $\mathrm{D}$ personality and eating habits together. Therefore, we decided to carry out this study.

\section{METHOD}

\section{Participants and Procedure}

This is a clinical observational study in a casecontrol type. This study was carried out in Aydın State Hospital between January 2019 and December 2019. Ethical approval for the study was obtained from the Kafkas University Faculty of Medicine Ethics Committee prior to the study. 
The estimated required sample size was found to be at least 36 individuals in each group for $\mathrm{d}=0.7$, $\mathrm{a}=0.05$, power $(1-\beta)=0.90$ and $\mathrm{N} 2 / \mathrm{N} 1=1$. The patient group consisted of 50 individuals who admitted to the General Surgery outpatient clinic of Aydın State Hospital for obesity surgery and the control group consisted of 50 healthy people with similar sociodemographic characteristics. The control group was created by randomly selecting staff from the hospital. The purpose and method of the study were explained to the participants. Verbal and written consent was obtained from those who agreed to participate in the study.

The inclusion criteria were determined as follows: being over the age of 18 years, being literate, and accepting to participate in the study. In addition, patients with a BMI of $35 \mathrm{~kg} / \mathrm{m} 2$ and above were included in the patient group, while those with a BMI between 18.9 and $24.9 \mathrm{~kg} / \mathrm{m} 2$ were included in the control group.

The exclusion criteria for the patients in the patient and control groups were determined as follows: the presence of mental retardation and psychotic disorder-schizophrenia-bipolar disorder diagnoses, refusing to participate in the study after information, and being illiterate.

\section{Measures}

All participants were asked to fill out the interview form containing sociodemographic characteristics such as age, gender, level of education, and employment status, which was prepared by the researchers. Beck Anxiety Inventory (BAI), Beck Depression Inventory (BDI), Childhood Trauma Questionnaire (CTQ), Type D Personality Scale (DS14), Arizona Sexual Experiences Scale (ASEX), Rosenberg Self-Esteem Scale (RSES), Quality of Life Scale (QOLS) and Eating Attitudes Test (EAT) were used.

Beck Depression Inventory: It is a 21 -item scale developed by Beck et al. (16) in 1961 and used to evaluate emotional, somatic, cognitive, and motivational symptoms seen in depression. Each expression is rated from 0 to 3 . The cut-off score is reported to be 17. Hisli et al. (17) performed the Turkish validity and reliability study of this scale.

Childhood Trauma Questionnaire: The CTQ is a self-report measure developed by Bernstein et al. (18). The Turkish validity and reliability study of the scale was performed by Şar et al. (19) and the internal consistency and test-retest reliability of the scale were found to be high. It has five subscales: emotional abuse, physical abuse, physical neglect, emotional neglect, sexual abuse.

Arizona Sexual Experiences Scale: The scale developed by McGahuey et al. (20) is a Likert-type scale consisting of five questions. The questions included in the scale are scored from 1 to 6 and the total score ranges from 5 to 30 . Low scores depict a sexual response to be as strong, easy, or satisfying while high scores depict sexual dysfunction. Soyka et al. (21) performed the Turkish validity and reliability study of the scale.

Beck Anxiety Inventory: It is used to identify the frequency of anxiety symptoms experienced by individuals. It is a Likert type scale consisting of 21 items. Each question is scored from 0 to 3 . High total scores depict the severity of anxiety experienced by the individual (22). The scale was translated into Turkish by Ulusoy et al. (23).

Rosenberg Self-Esteem Scale: The scale was developed by Rosenberg et al. (24) in 1963. It is a selfreport scale consisting of 63 questions and 12 subcategories. In the present study, the first 10 items of the scale were used to evaluate self-esteem levels. Çuhadaroğlu et al. (25) performed the Turkish validity and reliability study of the scale.

Quality of Life Scale: This scale used to evaluate the quality of life consists of subgroups that evaluate physical functionality, physical role difficulty, emotional role difficulty, energy/vitality, mental health, social functionality, pain, and general health perception (26). The Turkish reliability and validity study of this scale was carried out by Koçyiğit et al. (27).

Type D Personality Scale (DS-14): This scale was developed to evaluate NA, SI, and type D perso- 
nality. It consists of 14 items in total and two subscales measuring NA and SI levels. It is a Likert type scale in which each item scored from 0 to 4 (28). The cut-off point of both subscales is $\geq 10$. Test-retest validity of both subscales is good and internal validity is high (29).

Eating Attitude Test: The Turkish validity and reliability study of this scale, which was created by Garner and Garfinkel (30) was conducted by Savaşır and Erol (31). This scale consisting of 40 questions evaluates the disorders in the eating behaviors of individuals with and without eating disorders. High scores depict an increased risk of eating disorders.

\section{Statistical Analysis}

Statistical analysis was performed using SPSS (Statistical Package for Social Science) for Windows version 20.0. Kolmogorov-Smirnov test was used to determine whether the data were distributed normally. When comparing numerical variables between two groups, Student's t-test was used for variables following a normal distribution and the Mann-Whitney $U$ test was used for variables not following a normal distribution. Categorical variables were compared using the Chi-square test. The correlation between the two variables was identified using Spearman's Correlation Test. A p value of $<0.05$ was considered statistically significant.

\section{RESULTS}

Data belonging to a total of 100 individuals, 50 in the patient group and 50 in the control group, were evaluated. The mean age of the patient and control group was $37.14 \pm 11.11$ and $39 \pm 10.58$, respectively $(p=0.933)$. In the patient group, $74 \%$ of the patients were female and $26 \%$ were male whereas $54 \%$ of the patients in the control group were female and $46 \%$ were male $(\mathrm{p}=0.061)$. Of the individuals in the patient group, $40 \%$ were single and $60 \%$ were married whereas $12 \%$ of the individuals in the control group were single and $88 \%$ were married $(p=0.003)$. The rate of unemployed individuals was $34 \%$ in the patient group and $22 \%$ in the control group $(p=0.181)$. There was a statistically significant difference between the groups in terms of the level of education $(\mathrm{p}<0.0001)$ (Table 1).

Considering socio-demographic data, there was no significant difference between the patient group and the control group in terms of age, gender, and employment status, except for marital status and level of education (Table 1). There was no statistically significant difference between the groups in terms of BDI $(p=0.108)$ and BAI $(p=0.059)$ scores whereas a statistically significant difference was observed between the groups in terms of ASEX ( $\mathrm{p}<0.0001)$, CTQ $(\mathrm{p}<0.0001)$, QOLS $(\mathrm{p}<0.0001)$, RSES $(\mathrm{p}<0.0001)$, and EAT $(\mathrm{p}<0.0001)$ scores (Table 2). Type D Personality was present in $42 \%$ $(n=21)$ of the individuals in the patient group and $10 \%(n=5)$ of the individuals in the control group. A statistically significant difference was found between the two groups in terms of type D personality $(\mathrm{p}=0.001)$. (Table 2$)$

Standard multiple regression analysis was performed to evaluate education, self-esteem, eating attitude, childhood traumas, and the ability of type D personality to predict BMI. Preliminary analyzes

Table 1. Sociodemographic characteristics of groups

\begin{tabular}{llccccc}
\hline & & \multicolumn{2}{c}{ Patient $(\mathrm{n}=50)$} & \multicolumn{2}{c}{ Control $(\mathrm{n}=50)$} & p-value \\
& & $\mathrm{N}$ & $\%$ & $\mathrm{~N}$ & $\%$ & \\
\hline Age, Mean-SD & & \multicolumn{2}{c}{$37,14-11,11$} & $39-10.58$ & 0.933 \\
Gender & Female & 37 & 74 & 27 & 54 & 0.061 \\
& Male & 13 & 26 & 23 & 46 & \\
Marital Status & Married & 30 & 60 & 44 & 88 & 0.003 \\
Employment & Single & 20 & 40 & 6 & 12 & \\
& Yes & 33 & 66 & 39 & 78 & 0.181 \\
Educational Statur & No & 17 & 34 & 11 & 22 & \\
& Elementary & 9 & 18 & 0 & 0 & 0.000 \\
& Middle & 11 & 22 & 0 & 0 & \\
& High & 12 & 24 & 13 & 26 & \\
& University & 18 & 36 & 37 & 74 & \\
\hline
\end{tabular}

$\mathrm{p}<0.05$; SS:Standart Derivation 
Table 2. Comparison of the BDI, BAI, ASEX, RSES, CTQ, EAT scores of the patient and control groups

\begin{tabular}{lcccc}
\hline & Patient & Control & $\mathrm{t}$ & $\mathrm{p}$ \\
& Mean-SD & Mean-SD & & \\
\hline BDI & $10.10-9.392$ & $12.42-3.60$ & -5.61 & 0.108 \\
BAI & $9.48-17.31$ & $6.98-3.56$ & -6.78 & 0.059 \\
ASEX & $15.9-4.735$ & $11.36-3.193$ & -3.79 & 0.000 \\
RSES & $2.971-1.775$ & $0.643-0.935$ & -4.59 & 0.000 \\
CTQ & $43.08-15.35$ & $31.68-5.17$ & -10.45 & 0.001 \\
EAT & $23.96-9.664$ & $14.48-4.908$ & 6.178 & 0.000 \\
DS-14 & $20.48-12.94$ & $18.12-5.798$ & 1.177 & 0.000 \\
\hline
\end{tabular}

BDI; Beck Depression Inventory, BAI; Beck An xiety Inventory, ASEX; Arizona Sexual Experiences Scale, RSES:

Rosenberg Self-Esteem Scale, EAT; Eating Attitudes Test, CTQ; Childhood Trauma Questionnaire, DS-14; Type D

Personality Scale $\mathrm{p}<0.05$; SD:Standart Derivation

were conducted to investigate whether the normality, linearity, multiple common linearity, and homoscedasticity assumptions were neglected. Variance inflation factors (VIF) were found to be $<10$ and tolerance values were found to be $>0.2$. The model explains $63.5 \%$ of the variance $(\mathrm{F}[5$ $91]=31.63, p<0.001)$.In the model, only four control measures, which were education $(\mathrm{p}<0.001)$, self-esteem $(p<0.001)$, eating attitude $(p<0.001)$ and childhood traumas $(\mathrm{p}=0.006)$, were found statistically significant. The presence of type $\mathrm{D}$ personality diagnosis did not have any statistical contribution to the model $(\mathrm{p}=0.349)$. (Table 3$)$

\section{DISCUSSION}

In the present study, a difference has been observed between patients applying for surgical intervention and healthy individuals in terms of education, self-esteem, eating attitude, childhood traumas, sexual functionality, quality of life, and type D personality. However, type D personality has been found to have no ability to predict obesity, but it can predict scale scores related to education, self-esteem, eating attitude and childhood traumas.

Type D personality pattern has been statistically significantly higher in the individuals with obesity compared to healthy individuals. People with a Type D personality pattern, also known as dis- tressed personality, have a NA and SI (28). While people who are socially introverted are more likely to feel restless and depressed and they have lower self-confidence, hostile attitudes towards others, more physical complaints, and feeling oneself bad are more common in individuals with NA (28). Furthermore, individuals with lower self-esteem are people who have lost their vitality and energy, have low self-confidence, feel insignificant and incompetent, and are not able to use their abilities (32). In the present study, it has been observed that type D personality is more common and selfesteem is lower in individuals with obesity, indicating that our results are compatible with other studies. Body dissatisfaction is known to be common in individuals with obesity (33). We believe that these people will be expected to have type D personality patterns. The literature review has shown that there is no study investigating the relationship between type $\mathrm{D}$ personality and obesity. Therefore, we believe that our finding may be of great importance in this regard.

Considering the sociodemographic data of the individuals included in the present study, there has been no statistically significant difference between the two groups, except for the level of education. There are contradictory results in the literature in terms of the relationship between obesity and level of education (34). The difference in the present study might be due to the fact that the level of edu-

Table 3. Factors predicting obesity

\begin{tabular}{lllll}
\hline & Beta & Standart Error & Beta & $\mathrm{p}$ \\
\hline Constant & 33,023 & 3,520 & &, 000 \\
Education & $-4,208$ & 0,765 &,- 390 &, 000 \\
RSES & 1,909 & 0,406 &, 328 &, 000 \\
EAT &, 294 & 0,084 &, 249 &, 001 \\
CTQ &, 162 & 0,057 &, 195 &, 006 \\
DS-14 & 1,568 & 1,665 &, 065 &, 349 \\
\hline RSES:
\end{tabular}

RSES: Rosenberg Self-Esteem Scale, EAT: Eating Attitudes Test, CTQ; Childhood Trauma Questionnaire, DS -14; Type D Personality Scale, $\mathrm{p}<0.05$ 
cation of all healthy individuals in the control group is high school and above.

In the present study, the rate of disorders in the eating attitudes has been found to be statistically significantly higher in individuals with obesity, compatible with the literature (35). Eating attitude scale score has been found to be one of the factors predicting obesity. Uncontrolled eating behavior is an eating behavior disorder caused by psychological reasons, where excessive food intake is observed as a result of losing control in the eating action. Individuals with obesity experience high levels of uncontrolled eating attacks in negative emotional situations. Furthermore, there might be also uncontrolled eating behaviors induced by food deprivation due to continuous dieting. It is unknown whether eating attitude disorders are involved in the etiology of obesity or whether it is a result of obesity. Identifying and treating eating attitude disorders in bariatric surgery candidates may increase the success rate of surgeries.

Self-esteem is defined as self-evaluation, selfknowledge, self-respect, self-love, and self-confidence of a person and adopting his/her abilities and powers as they are (36). Self-esteem has spiritual, emotional and physical elements. The following factors are important in the formation of selfesteem: feeling valuable, being able to show their knowledge, skills, and abilities in life, being liked and accepted in the community, being loved, and accepting and adopting their own physical features (32). It is unknown whether low self-esteem and negative body perception observed in obese individuals are a result or a cause of obesity. There are studies in the literature showing that there is a relationship between obesity and decreased selfesteem in adults (37). Compatible with the literature, obesity has been found to be associated with self-esteem in the present study.

Stress experienced in the early years of life has been shown to cause changes in neuroendocrine system pathophysiology, psychological symptoms, and behavioral changes (38). Obesity is more common in people who are exposed to psychological traumas such as physical violence and sexual abuse in childhood (39). Individuals with a history of trau- ma see excessive body weight as an armor that protects him/herself from external factors (40). In a study involving 187 patients with obesity undergoing bariatric surgery, $61 \%$ of the cases were reported to have childhood abuse history whereas $21.8 \%$ exposed to sexual abuse (41). Compatible with the literature, the incidence of childhood traumas was significantly higher in the obesity group in the present study. There are also studies indicating that self-esteem is lower in adults with a traumatic experience (42). The data of our study are compatible with other studies in which self-esteem has been found to be lower in individuals with obesity.

We believe that our study will contribute to the literature in several areas. First of all, it may be beneficial for clinicians. If the psychological factors are taken into consideration both before and after surgery, it may contribute to short and long-term weight control in the postoperative period. Secondly, it may be useful for researchers. The etiology of obesity has not been fully clarified yet. Knowing the underlying factors may contribute to the treatment of obesity. Controlling obesity can contribute to the social and individual economy by reducing personal mortality and morbidity rates.

The present study has several limitations. Patients were not followed in the postoperative period. It is known that there are problems of compliance with the treatment program in the postoperative period and some of the individuals undergoing surgery regain the weight they lose. The effect of psychiatric disorders and environmental factors on these problems could not be investigated in this study. The small number of cases in both groups can be considered as another limitation of our study. Moreover, there was a statistically significant difference between the two groups in terms of educational levels, which is another limitation of our study. However, in our examination, the estimated required sample size was found to be at least 36 individuals in each group for $\mathrm{d}=0.7, \mathrm{a}=0.05$, power $(1-\beta)=0.90$, and $\mathrm{N} 2 / \mathrm{N} 1=1$. Therefore, our sample size can be considered sufficient. Studies with a larger sample size may increase the power of the results of our study.

In conclusion, sociodemographic characteristics, 
psychiatric factors, and personality patterns of bariatric surgery candidates have been investigated. The prevalence of type D personality, sexual dysfunction and low self-esteem, impaired quality of life, and childhood traumas have been higher in the obesity group compared to the control group. However, there has been no statistically significant difference between groups in terms of anxiety and depression scores. Furthermore, the level of education, self-esteem, eating attitudes, and childhood traumas have been found to be the predictive factors of BMI whereas type D personality is not one of those factors. At the present time, psychiatric examinations are routinely performed before

\section{REFERENCES}

1. Bray GA. Medical consequences of obesity. J Clin Endocrinol Metab 2004; 89:2583-2589.

2. Arslan E, Özçelik F, Demirbaş Ş. Obezite ile ilişkili kanser türleri. Anatol J Clin Invest 2013;7:176-184.

3. Fabricatore AN, Wadden TA, Sarwer DB, Faith MS. Depressive symptoms as a function of body mass index and health-related quality of life in the treatment seeking obese adults. Obes Res 2003; 11:10.

4. Fontaine KB, Cheskin LJ, Barofsky I. Health-related quality of life in obese persons seeking treatment. J Fam Pract 1996; 43:265-270.

5. Camps MA, Zervos E, Goode S, Rosemurgy AS. Impact of bariatric surgery on body image perception and sexuality in morbidly obese patients and their partners. Obes Surg 1996;,6:356360.

6. Rand CSW, Juldau JM, Robbins L. Surgery for obesity and marriage quality. JAMA 1982; 247:1419-1422.

7. Hedley AA, Ogden CL, Johnson CL, Carroll MD, Curtin LR, Flegal KM. Prevalence of overweight and obesity among US children, adolescents and adults. 1999-2002. JAMA 2004; 291:2847-2850.

8. Sağlık Bakanlığı. "Sağlıklı Beslenelim, Kalbimizi Koruyalım" Projesi Araştırma Raporu, Sağlık Bakanlığı Temel Sağlık Hizmetleri Genel Müdürlüğü, Ankara, 2004.

9. World Health Organisation. International Statistical Classification of Diseases and Related Health Problems, 10th Revision (ICD-10). Geneva, WHO, 1992.

10. Calle EE, Thun MJ, Petrelli JM, Rodriguez C, Heath CW: Body-Mass Index and mortality in a prospective cohort of U.S. adults. N Engl J Med 1999; 341:1097-1105.

11. Adams T, Gress M, Smith S, Halverson R, Simper S, Rosamond WD, Lamonte MJ, Stroup AM, Hunt SC. Long-term mortality after gastric bypass surgery. $\mathrm{N}$ Engl $\mathrm{J}$ Med 2007;357:753-761.

12. Schauer PR, Kashyap SR, Wolski K, Brethauer SA, Kirwan JP, Pothier CE, Thomas S, Abood B, Nissen SE, Bhatt DL. Bariatric surgery versus intensive medical therapy in obese patients with diabetes. N Engl J Med 2012;366:1567-1576. bariatric surgery. However, we believe that performing controls on a regular basis is important in the postoperative period and will increase the success rate of the surgery.

Correspondence address: Assis. Prof., Yüksel Kıvrak, Department of Psychiatry, Afyonkarahisar Health Sciences University Faculty of Medicine, Afyon, Turkey ykivrak21@gmail.com

13. Hsu LKG, Benotti PN, Dwyer J, Roberts SB, Saltzman E, Shikora, S, Rolls BJ, Rand W. Nonsurgical factors that influence the outcome of bariatric surgery: a review. Psychosom Med 1998; 60(3):338-346.

14. Starrenburg AH, Kraaier K, Pedersen SS, van Hout M, Scholten M, van der Palen J. Association of psychiatric history and type D personality with symptoms of anxiety, depression, and health status prior to ICD implantation. Int $\mathrm{J}$ Behav Med 2013; 20:425-433.

15. Williams L, O'Connor RC, Howard S, Hughes BM, Johnston DW, Hay JL, O'Connor DB, Lewis CA, Ferguson E, Sheey N, Grealy MA, O'Carroll RE. Type D personality mechanisms of effect: The role of health-related behaviour and social support. J Psychosom Res 2008; 64: 63-69.

16. Beck AT. An inventory for measuring depression. Arch Gen Psychiatry 1961;4:561-571.

17. Hisli N. Beck Depresyon Envanteri'nin geçerliği üzerine bir çalışma. Psikoloji Dergisi 1988; 6: 118-126.

18. Bernstein DP, Stein JA, Newcomb MD, Walker E, Pogge D, Ahluvalia T. Development and validation of a brief screening version of the Childhood Trauma Questionnaire. Child Abuse Negl 2003; 27(2): 169-198.

19. Şar V, Öztürk E, İkikardeş E. Çocukluk Çağı Ruhsal Travma Ölçeğinin (CTQ) Türkçe uyarlamasının geçerlik ve güvenilirliği. Türkiye Klinikleri J Med 2012;32:1054-63.

20. McGahuey CA, Gelenberg AJ, Laukes CA, Moreno FA, Delgado PL, McKnight KM, Manber R. The Arizona Sexual Experience Scale (ASEX): Reliability and validity. J Sex Marital Ther 2000;26: 25- 40.

21. Soykan A. The reliability and validity of Arizona Sexual Experiences Scale in Turkish ESRD patients undergoing hemodialysis. Int J Impot Res 2004;16:531-534.

22. Beck AT, Epstein N, Brown G, Steer RA. An inventory for measuring clinical anxiety: psychometric properties. J Consult Clin Psychol 1988;56: 893-897.

23. Ulusoy M, Şahin N, Erkmen H. Turkish version of the Beck Anxiety Inventory : Psychometric properties. J Cogn Psychother 1998;12:163-172. 
24. Rosenberg M, Society and the Adolescent Self-image, Princeton University Press, Princeton. 1965.

25. Çuhadaroğlu F. Adolesanlarda benlik saygısı. Uzmanlık Tezi. Hacettepe Üniversitesi Tıp Fakültesi Psikiyatr Anabilim Dalı, Ankara, 1986.

26. Sullivan M, Karlsson J ve Ware JE, Jr. The Swedish SF-36 Health Survey I.Evaluation of data quality, scaling assumptions, reliability and construct validityacross general populations in Sweden. Soc Sci Med 1995; 41:1349-1358.

27. Koçyiğit, H, Aydemir Ö, Ölmez N, Memiş A. Kısa form-36 (KF-36)'nın Türkçe versiyonunun güvenirliliği ve geçerliliği. İlaç ve Tedavi Dergisi 1999; 12: 102-106.

28. Denollet J. DS14: Standard assessment of negative affectivity, social inhibition, and Type D personality. Psychosom Med 2015;67:89-97.

29. Alçelik A, Yıldırım O, Canan F, Eroğlu M, Aktaş G, Savli H. A preliminary psychometric evaluation of the type $\mathrm{D}$ personality construct in Turkish hemodialysis patients. Journal of Mood Disorders 2012; 2:1-5.

30. Garner DM, Garfinkel PE. The Eating Attitudes Test: an index of the symptoms of anorexia nervosa. Psychol Med 1979; 9:273-279

31. Erol N, Savaşır I. Yeme Tutum Testi: Anoreksia nevroza belirtileri indeksi. Turk Psikoloji Dergisi 1989; 23:132-6.

32. Özkan D. Benlik saygısını etkileyen etmenler. Düşünen Adam Dergisi 1994;7:4-9.

33. Mond J, van den Berg P, Boutelle K, Hannan P, NeumarkSztainer D. Obesity, body dissatisfaction, and emotional wellbeing in early and late adolescence: findings from the project EAT study. J Adolesc Health 2011; 48: 373-8.

34. Baughman K, Logue Sutton K, Capers C, Jarjoura D, Smucker W. Biopsychosocial characteristics of overweight and obese primary care patients: do psychosocial and behavior factors mediate sociodemographic effects?. Prevent Med 2003; 37: $129-137$

35. Black DW, Goldstein RB, Mason EE. Prevalence of mental disorder in 88 morbidly obese bariatric clinic patients. Am J Psychiatry 1992;149:227-234.

36. Ogden J, Evans C. The problem with weighting: effects on mood, self-esteem and body image. Int $\mathrm{J}$ Obes Relat Metab Disord 1996; 20:272-277.

37. Deveci A, Demet M, Özmen B, Özmen E, Hekimsoy Z. Obez hastalarda psikopatoloji, aleksitimi ve benlik saygısı. Anadolu Psikiyatri Dergisi 2005; 6: 84-91.

38. D’Argenio A, Mazzi C, Pecchioli L, Di Lorenzo G, Siracusano A, Troisi A. Early trauma and adult obesity: Is psychological dysfunction the mediating mechanism? Physiol Behav 2009;98: 543-546.

39. Wiederman MW, Sansone RA, Sansone LA. Obesity among sexually abused women: An adaptive function for some? Women Health 1999;29:89-100.

40. Danielle LG, Sumit RM, Arya MS, Christian RC, Scott WK, Daniel WB, Shahzeer K, Linda M, Konrad F, Raj SP. Prevalence and predictors of self reported sexual abuse in severely obese patients in a population-based bariatric program. J Obes 2013;2:43-45.

41. Mamun A, Lawlor D, Callaghan M, Bor W, Williams G, Najman J. Does childhood sexual abuse predict young adult's BMI? A birth cohort study. Obesity 2007;15:2103-10.

42. Levitt JL. Treating eating disorder patients who have had traumatic experiences: A self-regulatory approach. Eat Disord 2007;15:359-372. 